\title{
Evaluation of the microbiological quality of minimally processed vegetables
}

\author{
Vanessa SCHUH ${ }^{1}$, Janaína SCHUH ${ }^{1}$, Nei FRONZA ${ }^{1}$, Fabiana Bortolini FORALOSSO ${ }^{1}$, Silvani VERRUCK ${ }^{2}$, \\ Alvaro VARGAS JUNIOR ${ }^{1}$ (D), Sheila Mello da SILVEIRA ${ }^{1 *}$
}

\begin{abstract}
The aim of this study was to evaluate the hygienic-sanitary quality of minimally processed vegetables commercialized in the city of Concórdia, Santa Catarina State, Brazil. Eight distinct products, sold in 3 different supermarkets, totalizing 24 samples were evaluated. Of the analyzed samples, just one was in discordance with the microbiological parameters established by the Brazilian legislation (210 MPN/g of coliforms at $45^{\circ} \mathrm{C}$ for Kale 2). Beyond the absence of Salmonella sp. indicated in legislation, all samples also indicated the absence of positive coagulase staphylococci and Listeria monocytogenes. The most expressive microbial counts were obtained when evaluating the aerobic mesophilic microorganisms (ranging from $2.8 \times 10^{2}$ to $2.7 \times 10^{7}$ ), and for molds and yeasts (ranging from $4.5 \times 10^{2}$ to $4.9 \times 10^{5}$ ). We highlight that the quality and shelf-life of minimally-processed vegetables directly depend on the handling throughout the production chain, since obtaining the raw material, to processing and commercialization. Thus, periodic evaluations of these products can reduce the risks to consumer health and favor the commercial expansion of the segment of fresh and minimally processed vegetables.
\end{abstract}

Keywords: minimally processed vegetables; hygiene; pathogenic microorganisms; food quality.

Practical Application: Hygienic-sanitary quality evaluation of minimally processed vegetables.

\section{Introduction}

The changes in food consumption have increased in the last decades, due to the fast pace of the population lifestyle, with less time to dedicate to food, which has led to the consumption of easy to prepare and convenient foods. On the other hand, consumers have obtained greater knowledge regarding the relationship between food and health, and the search for natural and healthy foods has increased. This tendency has been reflected on the growth of this segment in industry and in the popularity of ready for consumption vegetables, since they present characteristics similar to those in natura (Buckley et al., 2007; Ragaert et al., 2007; Putnik et al., 2017a, b). The minimally processed vegetables are an essential component of a healthy diet and a convenient form of increasing the consumption of fresh produce (Rico et al., 2007). The stages involving minimum processing are selection, prewashing, cutting or slicing, sanitizing, rinsing, centrifuging, packaging, and refrigeration, aiming to preserve the fresh product (Bolin \& Huxsoll, 1991; Oliveira \& Valle, 2000; Zambrano-Zaragoza et al., 2017).

One of the challenges of minimally processed vegetable production is to maintain the original characteristics of vegetables, since cutting causes the destruction of plant cells and changes in cellular metabolism. The cutting could also elevate respiratory activity and the production of ethylene, promoting the synthesis of enzymes involved in physiological and biochemical changes, as well as the induction of the metabolism of phenolic compounds and enzymatic darkening, which can result in sensorial alterations (Moretti, 2004).
Studies have shown that the most critical parameters to determine food quality are those related to the microbiological characteristics. Many relevant pathogenic and deteriorating microorganisms are isolated from minimally processed products and are associated with foodborne diseases or the reduced shelf life of the product, among which are the total and thermotolerant coliforms, Staphylococcus aureus, Salmonella, Listeria monocytogenes, and mesophile aerobic microorganisms (Cherry, 1999; Franco \& Landgraf, 2005; Silva \& Guerra, 2003; Vieites et al., 2004; Faour-Klingbeil et al., 2016).

To maintain the quality of minimally processed products, adequate storage is critical to retard the loss of moisture, nutritional and sensory characteristics, and minimize microbial growth. In this context, it is fundamental to maintain these products at suitable refrigeration temperature, from $0{ }^{\circ} \mathrm{C}$ to $5{ }^{\circ} \mathrm{C}$ since, in this temperature range, the products present an increased shelf-life (Rinaldi et al., 2009).

In this context, the aim of this study was to evaluate the microbiological quality of minimally processed vegetable samples commercialized in supermarkets of the municipality of Concordia, Santa Catarina State, Brazil.

\section{Materials and methods}

\subsection{Sample collection}

Eight types of minimally processed vegetables were evaluated, among which were lettuce, cabbage, alfalfa sprouts, kale, Italian salad (mix), tropical salad (mix), carrot, and fruit salad, sold in 
3 different supermarkets. The Italian salad mix was composed of crisp lettuce, purple lettuce, chicory and cherry tomatoes. The tropical salad mix contained American lettuce, purple lettuce, Italian chicory, and arugula. The fruit salad contained pineapple, melon, papaya, kiwi, strawberry, and mango. Three samples of each type of vegetable, from different batches and of the same brand were evaluated, totalizing 24 samples analyzed.

The samples were collected in supermarkets of the municipality of Concordia, Santa Catarina State, Brazil, within a period of one month. After the purchase, they were transported in an isothermal box with recyclable ice and taken to the laboratory for immediate analysis.

\subsection{Microbiological analyses}

Coliforms at $35^{\circ} \mathrm{C}$, coliforms at $45^{\circ} \mathrm{C}$, positive coagulase staphylococci and population of aerobic mesophylic microorganisms were evaluated according to American Public Health Association (2001). Yeast and mold counts and the analysis to determine the presence of Salmonella sp. were carried out according to the IN 62 methods (Brasil, 2003). The detection and identification of Listeria sp. were performed following the Bacteriological Analytical Manual/Food and Drug Administration Method (Food and Drug Administration, 2016).

For coliforms at $35^{\circ} \mathrm{C}$, coliforms at $45^{\circ} \mathrm{C}$, positive coagulase staphylococci, aerobic mesophylic microorganisms and yeast and mold counts, samples of $25 \pm 0.2 \mathrm{~g}$ were aseptically weighed, transferred to sterile stomacher bags, and homogenized for one minute in $225 \mathrm{~mL}$ of $0.1 \mathrm{~g} / 100 \mathrm{~mL}$ peptone water in a Bagmixer blender (Interscience, France). Samples were subsequently diluted in $0.1 \mathrm{~g} / 100 \mathrm{~mL}$ peptone water.

Population of aerobic mesophylic microorganisms was determined by pour-plate using Plate Count Agar (PCA). Samples were incubated at $36^{\circ} \mathrm{C}\left( \pm 1^{\circ} \mathrm{C}\right)$ for $48 \mathrm{~h}$. Yeast and molds counts were carried out by spread-plate on acidified Potato Dextrose Agar (PDA), incubated at $25^{\circ} \mathrm{C}\left( \pm 1^{\circ} \mathrm{C}\right)$ for 7 days.

Positive coagulase staphylococci was enumerated by surface inoculation on Baird Parker agar supplemented with egg yolk and potassium tellurite. Typical and atypical colonies were separately counted after $48 \mathrm{~h}$ incubation at $36^{\circ} \mathrm{C}\left( \pm 1^{\circ} \mathrm{C}\right)$. Six colonies of each type were transferred to tubes containing brain heart infusion $(\mathrm{BHI})$ broth, and incubated at $36^{\circ} \mathrm{C}\left( \pm 1^{\circ} \mathrm{C}\right)$ for $24 \mathrm{~h}$. These cultures were submitted to coagulase test using freeze-dried rabbit plasma.

Total coliforms (coliforms at $35^{\circ} \mathrm{C}$ ) and termo-tolerant coliforms (coliforms at $45^{\circ} \mathrm{C}$ ) were enumerated by inoculation in Lauryl Sulphate Triptose broth (LST) for the presumptive test followed by confirmative tests in Brilliant Green broth (BG) and Escherichia coli broth (EC), respectivelly. The final results of each group of coliforms were obtained from the table of the Most Probable Number (MPN) by the combination of the number of positive tubes, i.e., those showing turbidity and gas production.

For detection of Salmonella sp., a pre-enrichment of $25 \mathrm{~g}$ of sample was performed in $225 \mathrm{~mL}$ of buffered peptone water (BPW) which was incubated at $35^{\circ} \mathrm{C}\left( \pm 1^{\circ} \mathrm{C}\right)$ for $24 \mathrm{~h}$. Aliquots were transferred simultaneously to tetrathionate broth (TTB) and Rappaport-Vassiliadis broth (RV) and were incubated at $42{ }^{\circ} \mathrm{C}\left( \pm 1^{\circ} \mathrm{C}\right)$ for $24 \mathrm{~h}$. The selective enrichment cultures were streaked onto the surface of Brilliant-green Phenol-red Lactose Sucrose (BPLS) and Xylose Lysine Deoxycholate (XLD) agars, and they were incubated at $35^{\circ} \mathrm{C}\left( \pm 1^{\circ} \mathrm{C}\right)$ for $24 \mathrm{~h}$. The typical colonies of Salmonella sp. were submitted to biochemical screening in triple sugar iron agar (TSI), lysine iron agar (LIA), urea agar (UA), SIM medium and oxidase test.

For the detection and identification of Listeria sp., a pre-enrichment of $25 \mathrm{~g}$ of sample was performed in $225 \mathrm{~mL}$ of buffered Enrichment Listeria Broth (BLEB) which was incubated at $30^{\circ} \mathrm{C}\left( \pm 1^{\circ} \mathrm{C}\right)$ for $4 \mathrm{~h}$, followed by the addition of an acriflavin/nalidixic acid/ciclohexymide supplement, with additional incubation for $44 \mathrm{~h}$. A loopful of the pre-enrichment was streaked onto Oxford agar plates and incubated at $35^{\circ} \mathrm{C}$ $\left( \pm 1{ }^{\circ} \mathrm{C}\right)$ for $24-48$ hours. Typical colonies were transferred to Tripticase Soya Agar supplemented with yeast extract (TSA-YE), incubated at $30{ }^{\circ} \mathrm{C}\left( \pm 1{ }^{\circ} \mathrm{C}\right)$ for $24-48 \mathrm{~h}$. The identification of Listeria monocytogenes and other species of Listeria sp. was done using the standard miniaturized biochemical testing system, the API Listeria System (Biomeriux ${ }^{\circledast}$ ).

\subsection{Statistical analyses}

To determine significant differences $(P<0.05)$ between the results, one-way analysis of variance (ANOVA) and Tukey test was used. The data also were submitted to linear correlation $(R)$ from regression analysis. All statistical analyses were performed using Statistica version 13.3 (TIBCO Software Inc., Palo Alto, CA).

\section{Results and discussion}

One of the most important parameters involved in food quality is the food safety. The microbiological characteristics are one of the most important properties related to safe food consumption. The presence of pathogenic and deteriorating microorganisms has been extensively related to foodborne diseases or the reduced shelf life of minimally processed fruits and vegetables (Cherry, 1999; Franco \& Landgraf, 2005; Silva \& Guerra, 2003; Vieites et al., 2004; Faour-Klingbeil et al., 2016). The knowledge of the microbiological parameters of minimally processed vegetables and fruit can help in the decision-making related to the implementation of preventive strategies such as hygiene practices and Hazard Analysis Critical Control Points (HACCP) (Cocolin et al., 2011). Moreover, periodic evaluations of microbiological criteria established in legislation can also reduce the risks to the health of consumers and favor the commercial expansion of minimally processed vegetables and fruits. As these kind of product are ready-to-eat products, the Brazilian legislation establishes the microbiological standards of $1 \times 10^{2} \mathrm{CFU} / \mathrm{g}$ for vegetables and $5 \times 10^{2} \mathrm{CFU} / \mathrm{g}$ for fruits only for thermotolerant coliforms, as well as the absence of Salmonella sp. in $25 \mathrm{~g}$ for both (Brasil, 2001). In the same way, the European Union legislation established limits for E. coli $\left(1 \times 10^{2} \mathrm{CFU} / \mathrm{g}\right)$ and absence of Salmonella sp. in $25 \mathrm{~g}$ (European Union, 2007). Thus, the results that fit the Brazilian legislation for thermotolerant coliforms and Salmonella sp. found in the present study can also be extrapolated to the legislation of the European Union. 
The legislation does not mention a standard for total coliforms, but, according to Berbari et al. (2001) and Smanioto et al. (2009), samples with counts higher than $1.1 \times 10^{3} \mathrm{CFU} / \mathrm{g}$ are unfit for consumption. Therefore, according to this study, the samples of Lettuce 1 and 2, Kale 1 and 2, Cabbage 1, 2 and 3, Sprout 1, and Tropical salad 3 were unfit for consumption (Table 1), indicating failings in the Good Manufacturing Practices of the establishment.

According to Table 1, for thermotolerant coliforms, just one sample was in discordance with the microbiological parameters established by the Brazilian legislation (Kale 2). This high number of thermotolerant coliforms may have occurred due to hygiene problems during preparation by the food handler or in the sanitation of equipment and utensils, or even by the use of contaminated water, which may have contaminated the sample (Mendes et al., 2011). Furthermore, high counts of Enterobacteriaceae can occur in raw vegetables since some genera are part of the soil microbiota (Little et al., 1999; Johnston et al., 2005). The thermotolerant coliforms also presented a high positive correlation with Staphylococcus sp. $(\mathrm{R}=0.881, P<0.05)$, which emphasizes the attention that should be given to the Good Manufacturing Practices, mainly in the sanitization process and in the post-processing cross-contamination during the production of minimally processed vegetables and fruits.

Although the presence of Staphylococcus spp. has been related to minimally processed fruits and vegetables, Campaniello et al.
(2008) reported that its presence does not represent a risk once this species has disadvantages when in competition with other naturally present in raw fruits and vegetables. These authors also suggest that the presence of this genus of bacteria is mainly related to the contamination in the processing line by food handlers.

However, this type of contamination can become a problem when pathogens staphylococci contaminate samples, as occurs with Staphylococcus aureus. In this sense, it is important to highlight that positive coagulase staphylococci population was below the detection limit $(<100 \mathrm{CFU} / \mathrm{g})$ in all the samples analyzed in the present study (data not shown). Similar results were observed by Maistro et al. (2012), who evaluated the microbiological quality and safety of minimally processed vegetables commercialized in Campinas - SP, Brazil, in which none of the 172 samples evaluated presented Staphylococcus aureus. Likewise, Pinheiro et al. (2005) evaluated minimally processed fruit samples in Fortaleza-CE, Brazil, and also detect no coagulase positive Staphylococcus.

It is known that during the minimum processing there is intense manipulation of the food, which could favor the contamination by $S$. aureus. However, according to the results obtained, the intrinsic conditions of the fruit and the environmental conditions did not favor the establishment of this bacteria. It is worth mentioning that most studies on minimally processed vegetables did not study the presence of coagulase positive Staphylococcus because the production of enterotoxins does not occur at temperatures below $10^{\circ} \mathrm{C}$ (Oliveira et al., 2010a).

Table 1. Microbiological analyses of minimally processed vegetables and fruits.

\begin{tabular}{|c|c|c|c|c|c|}
\hline Sample & $\begin{array}{l}\text { Total coliforms } \\
\text { (MPN/g) }\end{array}$ & $\begin{array}{c}\text { Thermotolerant } \\
\text { coliforms (MPN/g) }\end{array}$ & $\begin{array}{c}\text { Staphylococcus sp. } \\
\text { (CFU/g) }\end{array}$ & $\begin{array}{l}\text { Mold and yeast } \\
\text { (CFU/g) }\end{array}$ & $\begin{array}{c}\text { Aerobic mesophilic } \\
\text { microorganisms } \\
(\mathrm{CFU} / \mathrm{g})\end{array}$ \\
\hline Lettuce 1 & $>1100$ & $<3$ & $4.2 \times 10^{2 b}$ & $1.0 \times 10^{4 \mathrm{a}}$ & $2.1 \times 10^{7 \mathrm{a}}$ \\
\hline Lettuce 2 & $>1100$ & $<3$ & $7.3 \times 10^{4 \mathrm{a}}$ & $7.3 \times 10^{3 \mathrm{a}}$ & $1.8 \times 10^{6 b}$ \\
\hline Lettuce 3 & 15 & $<3$ & $2.5 \times 10^{2 b}$ & $5.0 \times 10^{3 \mathrm{a}}$ & $1.6 \times 10^{4 c}$ \\
\hline Kale 1 & $>1100$ & $<3$ & $6.9 \times 10^{6 a}$ & $4.9 \times 10^{5 a}$ & $1.4 \times 10^{6 b}$ \\
\hline Kale 2 & $>1100$ & 210 & $1.7 \times 10^{7 \mathrm{a}}$ & $3.4 \times 10^{4 \mathrm{~b}}$ & $2.7 \times 10^{7 \dagger \mathrm{a}}$ \\
\hline Kale 3 & 460 & $<3$ & $3.2 \times 10^{3 b}$ & $1.9 \times 10^{5 \mathrm{a}}$ & $1.5 \times 10^{6 \mathrm{~b}}$ \\
\hline Cabbage 1 & $>1100$ & $<3$ & $4.2 \times 10^{3 b}$ & $6.4 \times 10^{3 \mathrm{a}}$ & $1.2 \times 10^{6 b}$ \\
\hline Cabbage 2 & 1100 & $<3$ & $2.9 \times 10^{3 b}$ & $1.6 \times 10^{3 \mathrm{~b}}$ & $3.1 \times 10^{4 c}$ \\
\hline Cabbage 3 & $>1100$ & $<3$ & $5.9 \times 10^{6 a}$ & $2.7 \times 10^{3 \mathrm{ab}}$ & $2.4 \times 10^{7 \mathrm{a}}$ \\
\hline Sprout 1 & $>1100$ & $<3$ & $6.5 \times 10^{4 a}$ & $9.3 \times 10^{3 \mathrm{~b}}$ & $1.5 \times 10^{7 \dagger a}$ \\
\hline Sprout 2 & 11 & $<3$ & $2.1 \times 10^{3 b}$ & $1.8 \times 10^{4 \mathrm{a}}$ & $8.0 \times 10^{6 b}$ \\
\hline Sprout 3 & 3 & $<3$ & $1.4 \times 10^{5 \mathrm{a}}$ & $6.4 \times 10^{2 c}$ & $2.1 \times 10^{6 c}$ \\
\hline Tropical salad 1 & 240 & $<3$ & $3.5 \times 10^{3 b}$ & $7.2 \times 10^{3 \mathrm{a}}$ & $1.6 \times 10^{4 c}$ \\
\hline Tropical salad 2 & 3 & $<3$ & $1.6 \times 10^{4 \mathrm{a}}$ & $4.5 \times 10^{3 \mathrm{a}}$ & $7.0 \times 10^{4 b}$ \\
\hline Tropical salad 3 & $>1100$ & $<3$ & $2.5 \times 10^{3 b}$ & $5.8 \times 10^{3} \mathrm{a}$ & $9.5 \times 10^{5 \mathrm{a}}$ \\
\hline Carrot 1 & $<3$ & $<3$ & $<100^{\dagger \mathrm{a}}$ & $6.8 \times 10^{3 b}$ & $4.3 \times 10^{3 \mathrm{~b}}$ \\
\hline Carrot 2 & $<3$ & $<3$ & $<100^{\dagger \mathrm{a}}$ & $1.0 \times 10^{4 \mathrm{a}}$ & $4.9 \times 10^{3} \mathrm{ab}$ \\
\hline Carrot 3 & 43 & $<3$ & $<100^{\dagger \mathrm{a}}$ & $<100^{\dagger c}$ & $7.6 \times 10^{3 \mathrm{a}}$ \\
\hline Fruit salad 1 & 150 & $<3$ & $9.0 \times 10^{2 b}$ & $3.0 \times 10^{4 \mathrm{a}}$ & $4.9 \times 10^{3 \mathrm{a}}$ \\
\hline Fruit salad 2 & $<3$ & $<3$ & $6.4 \times 10^{3 a}$ & $5.4 \times 10^{3 b}$ & $3.7 \times 10^{3 \mathrm{a}}$ \\
\hline Fruit salad 3 & 28 & $<3$ & $5.5 \times 10^{2 b}$ & $2.8 \times 10^{3 b}$ & $2.8 \times 10^{2 b}$ \\
\hline Italian salad 1 & 460 & $<3$ & $<100^{\dagger \mathrm{a}}$ & $4.5 \times 10^{2 b}$ & $5.3 \times 10^{5 \mathrm{a}}$ \\
\hline Italian salad 2 & 150 & $<3$ & $<100^{\dagger \mathrm{a}}$ & $1.9 \times 10^{4 \mathrm{a}}$ & $8.0 \times 10^{3 b}$ \\
\hline Italian salad 3 & 35 & $<3$ & $<100^{\dagger \mathrm{a}}$ & $1.4 \times 10^{4 \mathrm{a}}$ & $6.0 \times 10^{3 b}$ \\
\hline
\end{tabular}

${ }^{\dagger}$ Estimated values. Different superscript letters in a column denote significant differences $(\mathrm{P}<0.05)$ for the same kind of product. 
As shown in Table 1, the mold and yeast count was around $10^{3} \mathrm{CFU} / \mathrm{g}$ for most samples. The samples with the most expressive values, in the order of $10^{5} \mathrm{CFU} / \mathrm{g}$, were Kale 1 and 3, while the samples Lettuce 1, Kale 2, Carrot 2, Sprout 2, Fruit salad 1, and Italian salad 2 and 3 presented counts in the range of $10^{4} \mathrm{CFU} / \mathrm{g}$.

According to a study conducted in Campinas - SP, from July to December 2005, in which 155 samples of vegetables and 25 of minimally processed fruits commercialized in supermarkets, retail stores, and free fairs of the city were evaluated, the counts of molds and yeasts ranged between $<1 \times 10^{2} \mathrm{CFU} / \mathrm{g}$ and $2.5 \times 10^{6} \mathrm{CFU} / \mathrm{g}$, with a mean of $2.3 \times 10^{3} \mathrm{CFU} / \mathrm{g}$ (Santos et al., 2010). The count of yeast and mold for the kale samples ranged from $3.9 \times 10^{2} \mathrm{CFU} / \mathrm{g}$ to $1 \times 10^{5} \mathrm{CFU} / \mathrm{g}$, which shows that the samples evaluated in the present study, according to Table 1, presented higher microbiological counts, with values between $3.4 \times 10^{4}$ and $4.9 \times 10^{5} \mathrm{CFU} / \mathrm{g}$. These results indicate that these samples were more susceptible to deterioration because the minimally processed vegetables are exposed to the higher moisture content in the closed packages, which affect the shelf life of the products (Santos et al., 2010; Franco \& Landgraf, 2005).

By monitoring the temperature, it is possible to control the microbial growth and the respiratory and enzymatic activity of the plants, delaying possible undesirable transformations (Fantuzzi et al., 2004). It is essential to verify the sanitary conditions during production, processing, and commercialization, to minimize the deterioration caused by mold (Heard, 1999). Besides, the presence of some molds strains in fruits and vegetables may lead to health problems because of the production of mycotoxins (Tournas, 2005; Tournas et al., 2006).

The research conducted by Santos et al. (2010) showed the following values for molds and yeasts: for American lettuce, from $5.0 \times 10^{4} \mathrm{CFU} / \mathrm{g}$ to $7.9 \times 10^{9} \mathrm{CFU} / \mathrm{g}$, for garden lettuce, $1.2 \times 10^{6} \mathrm{CFU} / \mathrm{g}$ to $3.2 \times 10^{6} \mathrm{CFU} / \mathrm{g}$, for chopped kale, $1.6 \times 10^{7} \mathrm{CFU} / \mathrm{g}$ to $3.2 \times 10^{9} \mathrm{CFU} / \mathrm{g}$, for salads, $5 \times 10^{3} \mathrm{CFU} / \mathrm{g}$ to $1.6 \times 10^{9} \mathrm{CFU} / g$. Samples of alfalfa sprout were not evaluated. Thus, when comparing the results obtained for the salad mix samples (Italian salad and tropical salad), presented in Table 1, these results were inferior to those obtained by Santos et al. (2010), which also occurred for the lettuce and kale samples.

In the study conducted by Abadias et al. (2008), the molds and yeasts were present in the count from $1 \times 10^{2}$ to $6.3 \times 10^{7} \mathrm{CFU} / \mathrm{g}$ for the vegetables. For the processed fresh fruits, the authors obtained values ranging from $5 \times 10^{1}$ to $7.9 \times 10^{4} \mathrm{CFU} / \mathrm{g}$, while for the sprouts these values ranged from $6.3 \times 10^{2}$ to $3.98 \times 10^{7} \mathrm{CFU} / \mathrm{g}$. This study indicates that the samples of grated carrot and salad mix presented the highest counts, $1.2 \times 10^{6} \mathrm{CFU} / \mathrm{g}$, and $2.5 \times 10^{5} \mathrm{CFU} / \mathrm{g}$, respectively. In the present study, the results obtained for all samples, as presented in Table 1, were within the count range observed by these authors, apart from the Carrot 3 sample, which presented lower contamination levels. The samples of fruit salad and sprouts also presented values within the counting range cited by Abadias et al. (2008).

The count of aerobic mesophilic microorganisms from the samples evaluated in this study ranged from $2.8 \times 10^{2}$ to $2.7 \times 10^{7} \mathrm{CFU} / \mathrm{g}$. The current legislation RDC no 12 (Brasil, 2001) does not set limits for the total count of aerobic mesophilic microorganisms. However, there are a few international standards or recommendations that can be used as a comparison. According to Legnani \& Leoni (2004), France and Germany establish $5 \times 10^{7} \mathrm{CFU} / \mathrm{g}$ as the limit for the total count of aerobic mesophilic microorganisms in prepared ready-to-eat vegetables. According to this standard, $83.3 \%$ of the evaluated samples (20) would be in accordance with the legislation of these countries.

Aerobic microorganism counts in leafy vegetables have been well studied and typically range from $1 \times 10^{3}$ to $1 \times 10^{8} \mathrm{CFU} / \mathrm{g}$ (Ailes et al., 2008; Korir et al., 2016; Oliveira et al., 2010b; Soriano et al., 2000; Wood et al., 2015). These results resemble those obtained in this study. Another study, conducted in Finland by Nousiainen et al. (2016), showed a level of $10^{8} \mathrm{CFU} / \mathrm{g}$ in $74 \%$ of the processed leafy vegetables. The authors indicated that the results obtained may be due to the samples having been stored at temperatures superior to the recommended.

A study conducted by Seow et al. (2012) evaluated 125 samples of vegetables and fruits, among which were apple, orange, mango, tomato, carrot, lettuce, fresh salads, and sprouts marketed in Singapore. The mean count of mesophilic aerobes for the processed salads was of $3.16 \times 10^{6} \mathrm{CFU} / \mathrm{g}$, with values ranging from $6.3 \times 10^{5}$ to $2 \times 10^{7} \mathrm{CFU} / \mathrm{g}$. As established by Agri-Food \& Veterinary Authority of Singapore (Agri-Food \& Veterinary Authority, 2005), all samples were considered unfit for consumption since the aerobic bacterial count cannot be superior to $1 \times 10^{5} \mathrm{CFU} / \mathrm{g}$ in that country.

With regard to Salmonella sp., the minimally processed vegetables evaluated in this study provided satisfactory results, that is, they were free of this microorganism (data not shown). Similar results were found by Paula et al. (2009) who evaluated the quality of vegetables and fruits processed in supermarkets of Lavras-MG, Brasília-DF, and São Paulo-SP and verified the absence of Salmonella spp. for all samples. The absence of this microorganism in the vegetables is fundamental since it demonstrates that the consumer is not exposed to the risk of food infection.

In this context, similar results were also observed by Fröder et al. (2007), who reported that the vegetable samples were free from E.coli O157:H7 and Salmonella. Such results were also reported in a study conducted in the United States, in which 466 fresh vegetables of american and mexican origin were evaluated, including green leaves, herbs and melons (Johnston et al., 2006).

All of the samples analyzed showed absence of Listeria monocytogenes (data not shown). However, in the samples of Kale 2 and 3, we observed the isolation of other species of this genus, such as Listeria ivanovii in the Cabbage 2 sample and Listeria grayi in the Cabbage 3 sample. According to Tresseler et al. (2009), the species of Listeria found are not pathogenic, but their presence in the food is a warning, demanding greater control during the vegetable processing.

According to a survey conducted in the southern United States from 2000 to 2002, in which 398 samples of various vegetables, including kale, were evaluated, the presence of Listeria monocytogenes was not detected (Johnston et al., 2005). 
In a study conducted in Northern Ireland, this microorganism was also not isolated (McMahon \& Wilson, 2001).

Statistical analysis showed that the data were randomized between fruit/vegetables and different supermarkets, thus, relation between higher counts of a kind of vegetable and a supermarket could not be established in the present study. The counts of samples from a specific brand also could not be related with problems in GMP of the company. In view of this study, we highlight that many factors can influence the final quality of minimally processed vegetables and deserve attention. Among these are the cultivation and postharvest conditions; processing conditions; time and temperature at which the product is maintained throughout the production chain until its commercialization, in order to provide the consumer with a microbiologically safe product (Santos et al., 2010).

\section{Conclusion}

The minimally processed vegetables commercialized in the municipality of Concórdia-SC, Brazil, met the microbiological parameters established by the current legislation, RDC $\mathrm{n}^{\circ} 12$ (Brasil, 2001) for "fresh, refrigerated, cut or frozen vegetables for direct consumption" and for "fresh fruits, in natura, prepared, chilled or frozen, for direct consumption ", instead the kale sample.

The results also indicate that the evaluated samples were handled under adequate hygienic conditions. The most significant contamination was related to the count of mesophilic aerobic microorganisms, and molds and yeasts, which may have occurred due to a higher bacterial load from the raw material, inadequate storage in some of the production stages or an inadequate sanitation process. These factors can influence the deterioration of vegetables, reducing their shelf life and making the product unfit for consumption.

Finally, we highlight the importance of conducting periodic evaluations of these products, which can reduce the risks to the health of consumers and favor the commercial expansion of fresh and minimally processed vegetables.

\section{References}

Abadias, M., Usall, J., Anguera, M., Solsona, C., \& Viñas, I. (2008). Microbiological quality of fresh, minimally-processed fruit and vegetables, and sprouts from retail establishments. International Journal of Food Microbiology, 123(1-2), 121-129. http://dx.doi. org/10.1016/j.ijfoodmicro.2007.12.013. PMid:18237811.

Agri-Food \& Veterinary Authority - AVA. (2005). Sales of food act. In Agri-Food \& Veterinary Authority - AVA. Food regulations, eleventh schedule, microbiological standard for food (Chap. 283, Vol. 56, No. 1). Singapore: AVA. Retrieved from http://www.ava.gov.sg/

Ailes, E. C., Leon, J. S., Jaykus, L.-A., Johnston, L. M., Clayton, H. A., Blanding, S., Kleinbaum, D. G., Backer, L. C., \& Moe, C. L. (2008). Microbial concentrations on fresh produce are affected by postharvest processing, importation, and season. Journal of Food Protection, 71(12), 2389-2397. http://dx.doi.org/10.4315/0362-028X-71.12.2389. PMid:19244889.

American Public Health Association - APHA. (2001). Compendium of methods for the microbiological examination of foods (4th ed.). Washington: APHA.
Berbari, S. A. G., Paschoalino, J. E., \& Silveira, N. F. A. (2001). Efeito do cloro na água de lavagem para desinfecção de alface minimamente processada. Food Science and Technology, 21(2), 197-201. http:// dx.doi.org/10.1590/S0101-20612001000200014.

Bolin, H. R., \& Huxsoll, C. C. (1991). Effect of preparation procedures and storage parameters on quality retention of salad cut lettuce. Journal of Food Science, 56(1), 60-67. http://dx.doi.org/10.1111/j.1365-2621.1991. tb07975.x.

Brasil, Ministério da Saúde. Agência Nacional de Vigilância Sanitária. (2001, January 10). Aprova o regulamento técnico sobre padrões microbiológicos para alimentos (Resolução RDC n ${ }^{\circ} 12$, de 2 de janeiro de 2001). Diário Oficial da República Federativa do Brasil.

Brasil, Ministério da Agricultura Pecuária e Abastecimento. (2003, September 18). Métodos analíticos oficiais para análises microbiológica para controle de produtos de origem animal e água (Instrução normativa $\mathrm{n}^{\circ} 62$, de 26 de agosto de 2003). Diário Oficial da União, seção 1.

Buckley, M., Cowan, C., \& Mccarthy, M. (2007). The convenience food market in Great Britain: convenience food lifestyle (CFL) segments. Appetite, 49(3), 600-617. http://dx.doi.org/10.1016/j. appet.2007.03.226. PMid:17537540.

Campaniello, D., Bevilacqua, A., Sinigaglia, M., \& Corbo, M. R. (2008). Chitosan: antimicrobial activity and potential applications for preserving minimally processed strawberries. Food Microbiology, 25(8), 9921000. http://dx.doi.org/10.1016/j.fm.2008.06.009. PMid:18954735.

Cherry, J. P. (1999). Improving the safety of fresh produce with antimicrobial. Food Technology, 53(11), 54-59.

Cocolin, L., Rajkovic, A., Rantsiou, K., Uyttendaele, M. (2011). The challenge of merging food safety diagnostic needs with quantitative PCR platforms. Trends in Food Science and Technology, 22, S30-S38. http://dx.doi.org/10.1016/j.tifs.2011.02.009.

European Union. (2007, December 7). Commission Regulation (EC) $\mathrm{n}^{\circ} 1441 / 2007$ of 5 December 2007 amending Regulation (EC) $\mathrm{n}^{\circ}$ 2073/2005 on microbiological criteria for foodstuffs. Official Journal of the European Union, L322, 12-29.

Fantuzzi, E., Puschmann, R., \& Vanetti, M. C. D. (2004). Microbiota contaminante em repolho minimamente processado. Food Science and Technology, 24(2), 207-211. http://dx.doi.org/10.1590/S010120612004000200008

Faour-Klingbeil, D., Murtada, M., Kuri, V., \& Todd, E. C. (2016). Understanding the routes of contamination of ready-to-eat vegetables in the Middle East. Food Control, 62, 125-133. http:// dx.doi.org/10.1016/j.foodcont.2015.10.024.

Food and Drug Administration - FDA. (2016). BAM: detection and enumeration of Listeria monocytogenes. In K. Jinneman, W. Burkhardt, M. Davidson, P. Feng, B. Ge, G. Gharst, T. Hammack, S. Himathongkham, J. Kase \& P. Regan (Eds.), Bacteriological analytical manual. Silver Spring: FDA.

Franco, B. D. G. M., \& Landgraf, M. (2005). Microbiologia dos alimentos. São Paulo: Atheneu.

Fröder, H., Martins, C. G., De Souza, K. L. O., Landgraf, M., Franco, B. D. G. M., \& Destro, M. T. (2007). Minimally processed vegetable salads: microbial quality evaluation. Journal of Food Protection, 70(5), 1277-1280. http://dx.doi.org/10.4315/0362-028X-70.5.1277. PMid:17536694.

Heard, G. (1999). Microbial safety of ready-to-eat salads and minimally processed vegetables and fruits. Food Australia, 51, 414-420.

Johnston, L. M., Jaykus, L. A., Moll, D., Martinez, M. C., Anciso, J., Mora, B., \& Moe, C. L. (2005). A field study on the microbiological quality of fresh produce. Journal of Food Protection, 68(9), 1840-1847. http://dx.doi.org/10.4315/0362-028X-68.9.1840. PMid:16161682.

Johnston, L. M., Jaykus, L.-A., Moll, D., Anciso, J., Mora, B., \& Moe, C. L. (2006). A field study of the microbiological quality of fresh 
produce of domestic and Mexican origin. International Journal of Food Microbiology, 112(2), 83-95. http://dx.doi.org/10.1016/j. ijfoodmicro.2006.05.002. PMid:17045687.

Korir, R. C., Parveen, S., Hashem, F., \& Bowers, J. (2016). Microbiological quality of fresh produce obtained from retail stores on eastern shore of Maryland, United States of America. Food Microbiology, 56, 2934. http://dx.doi.org/10.1016/j.fm.2015.12.003. PMid:26919815.

Legnani, P. P., \& Leoni, E. (2004). Effect of processing and storage conditions on the microbiological quality of minimally processed vegetables. International Journal of Food Science \& Technology, 39(10), 1061-1068. http://dx.doi.org/10.1111/j.1365-2621.2004.00891.x.

Little, C. L., Roberts, D., Youngs, E., \& de Louvois, J. (1999). Microbiological quality retail imported unprepared whole lettuce: a PHLS food working group study. Journal of Food Protection, 62(4), 325-328. http://dx.doi.org/10.4315/0362-028X-62.4.325. PMid:10419203.

Maistro, L. C., Miya, N. T. N., Sant'Ana, A. S., \& Pereira, J. L. (2012). Microbiological quality and safety of minimally processed vegetables marketed in Campinas, SP e Brazil, as assessed by traditional and alternative methods. Food Control, 28(2), 258-264. http://dx.doi. org/10.1016/j.foodcont.2012.05.021.

McMahon, M. A. S., \& Wilson, I. G. (2001). The occurrence of enteric pathogens and Aeromas species in organic vegetables. International Journal of Food Microbiology, 70(1-2), 155-162. http://dx.doi. org/10.1016/S0168-1605(01)00535-9. PMid:11759753.

Mendes, C. M., Santos, K. C., \& Oliveira, N. L. C. (2011). Pesquisa de coliformes totais e termotolerantes em alimentos minimamente processados, comercializados na cidade de Uberlândia, MG. Higiene Alimentar, 25(198-199), 58-61.

Moretti, C. L. (2004). Panorama do processamento mínimo de hortaliças. In Anais do $3^{\circ}$ Encontro Nacional sobre Processamento Mínimo de Frutas e Hortaliças (pp. 1-8). Viçosa: UFV.

Nousiainen, L.-L., Joutsen, S., Lunden, J., Hänninen, M.-L., \& FredrikssonAhomaa, M. (2016). Bacterial quality and safety of packaged fresh leafy vegetables at the retail level in Finland. International Journal of Food Microbiology, 232, 73-79. http://dx.doi.org/10.1016/j. ijfoodmicro.2016.05.020. PMid:27257744.

Oliveira, A. M., Miya, N. T. N., Sant'ana, A. S., \& Pereira, J. L. (2010a). Behavior and enterotoxin production by coagulase negative Staphylococcus in cooked ham, reconstituted skimmed milk, and confectionery cream. Journal of Food Science, 75(7), 475-481. http:// dx.doi.org/10.1111/j.1750-3841.2010.01754.x. PMid:21535559.

Oliveira, E. C. M., \& Valle, R. H. P. (2000). Aspectos microbiológicos de produtos hortícolas minimamente processados. Higiene Alimentar, 14(78-79), 50-54.

Oliveira, M., Usall, J., Vinas, I., Anguera, M., Gatius, F., \& Abadias, M. (2010b). Microbiological quality of fresh lettuce from organic and conventional production. Food Microbiology, 27(5), 679-684. http:// dx.doi.org/10.1016/j.fm.2010.03.008. PMid:20510788.

Paula, N. R. F., Vilas Boas, E. V. B., Rodrigues, L. J., Carvalho, R. A., \& Piccoli, R. H. (2009). Qualidade de produtos minimamente processados e comercializados em gôndolas de supermercados nas cidades de lavras - MG, Brasília - DF e São Paulo - SP. Ciência e Agrotecnologia, 33(1), 219-227. http://dx.doi.org/10.1590/S141370542009000100031.

Pinheiro, N. M. S., Figueiredo, E. A. T., Figueiredo, R. W., Maia, G. A., \& Souza, P. H. M. (2005). Avaliação da qualidade microbiológica de frutos minimamente processados comercializados em supermercados de Fortaleza. Revista Brasileira de Fruticultura, 27(1), 153-156. http:// dx.doi.org/10.1590/S0100-29452005000100040.

Putnik, P., Bursać Kovacević, D., Herceg, K., Roohinejad, S., Greiner, R., Bekhit, A. E.-D. A., \& Levaj, B. (2017a). Modelling the shelf-life of minimally-processed fresh-cut apples packaged in a modified atmosphere using food quality parameters. Food Control, 81, 55-64. http://dx.doi.org/10.1016/j.foodcont.2017.05.026.

Putnik, P., Roohinejad, S., Greiner, R., Granato, D., Bekhit, A. E.-D. A., \& Bursać Kovačević, D. (2017b). Prediction and modeling of microbial growth in minimally processed fresh-cut apples packaged in a modified atmosphere: a review. Food Control, 80, 411-419. http:// dx.doi.org/10.1016/j.foodcont.2017.05.018.

Ragaert, P., Devlieghere, F., \& Debevere, J. (2007). Role of microbiological and physiological spoilage mechanisms during storage of minimally processed vegetables. Postharvest Biology and Technology, 44(3), 185-194. http://dx.doi.org/10.1016/j.postharvbio.2007.01.001.

Rico, D., Martín-Diana, A. B., Barat, J. M., \& Barry-Ryan, C. (2007). Extending and measuring the quality of fresh-cut fruit and vegetables: a review. Trends in Food Science \& Technology, 18(7), 373-386. http:// dx.doi.org/10.1016/j.tifs.2007.03.011.

Rinaldi, M. M., Benedetti, B. C., Sarantópoulos, C. I. G. L., \& Moretti, C. L. (2009). Estabilidade de repolho minimamente processado sob diferentes sistemas de embalagem. Food Science and Technology, 29(2), 310-315. http://dx.doi.org/10.1590/S0101-20612009000200012.

Santos, T. B. A., Silva, N., Junqueira, V. C. A., \& Pereira, J. L. (2010). Microrganismos indicadores em frutas e hortaliças minimamente processadas. Brazilian Journal of Food Technology, 13(2), 141-146. http://dx.doi.org/10.4260/BJFT2010130200019.

Seow, J., Ágoston, R., Phua, L., \& Yuk, H.-G. (2012). Microbiological quality of fresh vegetables and fruits sold in Singapore. Food Control, 25(1), 39-44. http://dx.doi.org/10.1016/j.foodcont.2011.10.017.

Silva, M. Z. T., \& Guerra, N. B. (2003). Avaliação das condições de frutos minimamente processados. Higiene Alimentar, 17(111), 29-36.

Smanioto, T. F., Pirolo, N. J., Simionato, E. M. R. S. L., Arruda, M. C. (2009). Qualidade microbiológica de frutas e hortaliças minimamente processadas. Revista do Instituto Adolfo Lutz, 68(1), 150-154.

Soriano, J. M., Rico, H., Moltó, J. C., \& Mañes, J. (2000). Assessment of the microbiological quality and wash treatments of lettuce served in university restaurants. International Journal of Food Microbiology, 58(1-2), 123-128. http://dx.doi.org/10.1016/S0168-1605(00)002889. PMid:10898470.

Tournas, V. H. (2005). Moulds and yeasts in fresh and minimally processed vegetables, and sprouts. International Journal of Food Microbiology, 99(1), 71-77. http://dx.doi.org/10.1016/j.ijfoodmicro.2004.08.009. PMid:15718030.

Tournas, V. H., Heeres, J., \& Burgess, L. (2006). Moulds and yeasts in fruit salads and fruit juices. Food Microbiology, 23(7), 684-688. http:// dx.doi.org/10.1016/j.fm.2006.01.003. PMid:16943069.

Tresseler, J. F. M., Figueiredo, E. A. T., Figueiredo, R. W., Machado, T. F., Delfino, C. M., \& Sousa, P. H. M. (2009). Avaliação da qualidade microbiológica de hortaliças minimamente processadas. Ciência e Agrotecnologia, 33(spe), 1722-1729. http://dx.doi.org/10.1590/ S1413-70542009000700004.

Vieites, R. L., Evangelista, R. M., Campos, A. J., \& Moreira, G. C. (2004). Avaliação da contaminação microbiana do mamão minimamente processado e irradiado. Higiene Alimentar, 18(1), 65-70.

Wood, J. L., Chen, J. C., Friesen, E., Delaquis, P., \& Allen, K. J. (2015). Microbiological survey of locally grown lettuce sold at farmers' markets in Vancouver, British Columbia. Journal of Food Protection, 78(1), 203-208. http://dx.doi.org/10.4315/0362-028X.JFP-14-199. PMid:25581197.

Zambrano-Zaragoza, M. L., Quintanar-Guerrero, D., Del Real, A., Piñon-Segundo, E., \& Zambrano-Zaragoza, J. F. (2017). The release kinetics of $\beta$-carotene nanocapsules/xanthan gum coating and quality changes in fresh-cut melon (cantaloupe). Carbohydrate Polymers, 157, 1874-1882. http://dx.doi.org/10.1016/j.carbpol.2016.11.075. PMid:27987907. 